\title{
STRUKTUR DAN KOMPOSISI VEGETASI SEBAGAI DASAR RESTORASI DEGRADASI HUTAN DI KAWASAN PERLINDUNGAN BLOK SINTANG PT FINNANTARA INTIGA
}

\author{
(Vegetation Structure and Composition as a Baseline Data for Forest Degradation Restoration \\ in Sintang Block PT. Finnantara Intiga)
}

\author{
ER. Setiadharma 1), Burhanuddin 2), M. Sofwan Anwari ${ }^{2)}$ \\ 1) Mahasiswa Pasca Sarjana, Fakultas Kehutanan Universitas Tanjungpura, Jalan Imam Bonjol 78124, \\ Indonesia \\ ${ }^{2)}$ Dosen Pasca Sarjana, Fakultas Kehutanan Universitas Tanjungpura, Jalan Imam Bonjol 78124, \\ Indonesia \\ e-mail: edi.rustadi2912@gmail.com
}

\begin{abstract}
This study aims to examine the composition and structure of the vegetation in the protected forest area of PT Finnantara Intiga's Sintang block and determine the pattern of forest restoration and the types of vegetation that will be used for restoration of degraded forests. This research was conducted at PT Finnantara Intiga Sintang Block which is located in five land cover areas, of which three are reference secondary swamp forest (KPPN, KPSL and river border) and two areas are degraded forest (shrub and open land). This study uses a survey method with a line plot system. The sample was determined by means of purposive sampling. Based on the results of research data analysis, the number of species found at all levels at the KPSL location was nine species, at the KPPN location there were eleven species, at the River Border location there were eight species, at the Semak Belukar location there were seven species and at the Open Land location there were four species. In general, the horizontal structure of forest stands in damaged forest ecosystems is below the horizontal structure of natural forest stands as a reference. This shows that the level of vegetation density at the location of shrubs and open land has decreased so that forest restoration measures are needed to increase the density closer to natural forest ecosystems that have not been damaged. The pattern of forest restoration for scrub areas and open land referring to the Guidelines for Restoration in Conservation Areas (JICA, 2014) is natural succession. The pattern of forest restoration that will be implemented must take into account the physical conditions of the field and local socio-cultural considerations based on stakeholder considerations. The type of vegetation for enrichment and planting activities at the shrub location refers to the KPSL location as a reference because it tends to have similarities with the community similarity index of $52.03 \%$. The type of vegetation for enrichment and planting activities on open land locations refers to the KPPN location as a reference because it tends to have similarities with the community similarity index of $52.17 \%$.
\end{abstract}

Keywords: structure, composition, restoration, forest degradation

Abstrak

Penelitian ini bertujuan untuk mengkaji komposisi dan struktur vegetasi di kawasan hutan perlindungan blok Sintang PT Finnantara Intiga serta menentukan pola pemulihan hutan dan jenis vegetasi yang akan digunakan untuk restorasi hutan terdegradasi. Penelitian ini dilaksanakan di PT Finnantara Intiga Blok Sintang yang terletak di lima areal tutupan lahan, dimana tiga areal sebagai hutan rawa sekunder referensi (KPPN, KPSL dan sempadan sungai) dan dua areal di hutan yang terdegradasi (semak belukar dan lahan terbuka). Penelitian ini menggunakan metode survey dengan cara jalur berpetak. Sampel ditentukan dengan cara Purposive Sampling. Berdasarkan hasil analisis data penelitian, Jumlah jenis yang ditemui di 
semua tingkatan di lokasi KPSL ada sembilan jenis, dilokasi KPPN ada sebelas jenis, di lokasi Sempadan Sungai ada delapan jenis, di lokasi Semak Belukar ada tujuh jenis dan di lokasi Lahan Terbuka ada empat jenis. Secara umum bentuk grafik struktur horizontal tegakan hutan pada ekosistem hutan yang mengalami kerusakan berada di bawah grafik struktur horizontal tegakan hutan alam yang menjadi referensi. Hal ini menunjukkan bahwa tingkat kerapatan vegetasi pada lokasi semak belukar dan lahan terbuka mengalami penurunan sehingga diperlukan tindakan pemulihan hutan untuk meningkatkan kerapatan mendekati ekosistem hutan alam yang belum mengalami kerusakan. Pola pemulihan hutan untuk areal semak belukar dan lahan terbuka merujuk pada Pedoman Tata Cara Restorasi di Kawasan Konservasi (JICA, 2014) adalah suksesi alami. Pola pemulihan hutan yang akan dilaksanakan harus mempertimbangkan kondisi fisik lapangan dan sosial budaya setempat berdasarkan pertimbangan stakeholder. Jenis vegetasi untuk kegiatan pengkayaan dan penanaman pada lokasi semak belukar mengacu pada lokasi KPSL sebagai referensi karena kecenderungan memiliki kemiripan dengan dengan indeks kesamaan komunitas sebesar 52,03\%. Jenis vegetasi untuk kegiatan pengkayaan dan penanaman pada lokasi lahan terbuka mengacu pada lokasi KPPN sebagai referensi karena kecenderungan memiliki kemiripan dengan dengan indeks kesamaan komunitas sebesar 52,17\%.

Kata kunci: struktur, komposisi, restorasi, degradasi hutan

\section{PENDAHULUAN}

Indonesia dianugerahi dengan iklim tropis yang terdiri atas lebih dari 17.000 buah pulau yang terletak di antara 2 (dua) benua, Asia dan Australia, dan di antara 2 (dua) samudera, Samudera Pasifik dan Samudera India. Lokasi geografis ini menyebabkan Indonesia memiliki tingkat keanekaragaman hayati dan endemisitas yang sangat tinggi, dan memiliki tingkat keanekaragaman hayati lebih tinggi dari negara lain di dunia, kecuali Brasil dan Kolombia. Mengacu pada Indonesian Biodiversity Strategy and Action Plan (IBSAP) 2015-2020 (BAPPENAS, 2016), Indonesia tercatat memiliki 91.251 jenis tumbuhan berspora, 120 jenis gymnospermae, serta sekitar 30.000-40.000 jenis tumbuhan berbunga (angiospermae), yang dari perkiraan tersebut, hingga saat ini baru terindentifikasi $\quad 19.112$ jenis. Kelimpahan flora dan fauna di Indonesia yang sangat tinggi ini terancam dengan adanya deforestasi dan degradasi hutan. Pengelolaan yang kurang bijaksana menjadi penyebab hutan Indonesia mengalami kerusakan. Salah satu upaya yang dilakukan untuk mengurangi kerusakan yaitu dengan melakukan restorasi.

PT Finnantara Intiga Blok Sintang memiliki kawasan hutan terdegradasi dalam kawasan perlindungannya. Terjadinya degradasi hutan ini dapat mengganggu peranan kawasan perlindungan Blok Sintang bagi kehidupan masyarakat sekitar, terutama dalam perlindungan fungsi hidroorologis dan keanekaragaman hayati. . Berdasarkan hal tersebut, maka perlu adanya upaya restorasi (pemulihan) kawasan perlindungan Blok Sintang. Restorasi hutan yang mengalami kerusakan harus dilakukan dengan tujuan utama untuk mengembalikan komposisi dan struktur vegetasi mendekati kondisi semula sebelum terjadinya kerusakan, sehingga 
ekosistem hutan tersebut dapat menjalankan peran dan fungsinya sebagai kawasan hutan konservasi.

Kegiatan restorasi kawasan perlindungan ini diharapkan dapat berjalan dengan baik dan berhasil, maka perlu terlebih dahulu diketahui kondisi komposisi dan struktur vegetasi di kawasan hutan perlindungan blok Sintang, baik pada hutan yang masih baik kondisinya (hutan referensi) maupun pada kawasan hutan yang mengalami kerusakan. Kondisi referensi merupakan komponen penting dalam kegiatan restorasi kawasan hutan lindung. Restorasi ekologi dapat ditentukan hanya melalui penetapan kondisi-kondisi referensi (Kamada, 2005).

Penelitian ini bertujuan untuk (1) mengkaji komposisi dan struktur vegetasi di kawasan hutan perlindungan blok Sintang PT Finnantara Intiga, (2) menentukan pola pemulihan hutan berdasarkan hasil analisis komposisi dan jenis vegetasi yang akan digunakan untuk restorasi hutan terdegradasi.

\section{METODE PENELITIAN}

\section{Lokasi dan Waktu Penelitian}

Penelitian ini dilaksanakan di PT Finnantara Intiga Blok Sintang pada bulan April-Mei 2020 selama \pm 2 bulan. Lokasi penelitian terletak di lima areal tutupan lahan, dimana tiga areal sebagai hutan rawa sekunder referensi yaitu Kawasan Pelestarian Plasma Nutfah (KPPN), Kawasan Perlindungan Satwa Liar (KPSL) dan sempadan sungai serta dua areal di hutan yang terdegradasi (semak belukar dan lahan terbuka). Secara administrasi lokasi ini termasuk Kecamatan Ketungau, Kabupaten Sintang.

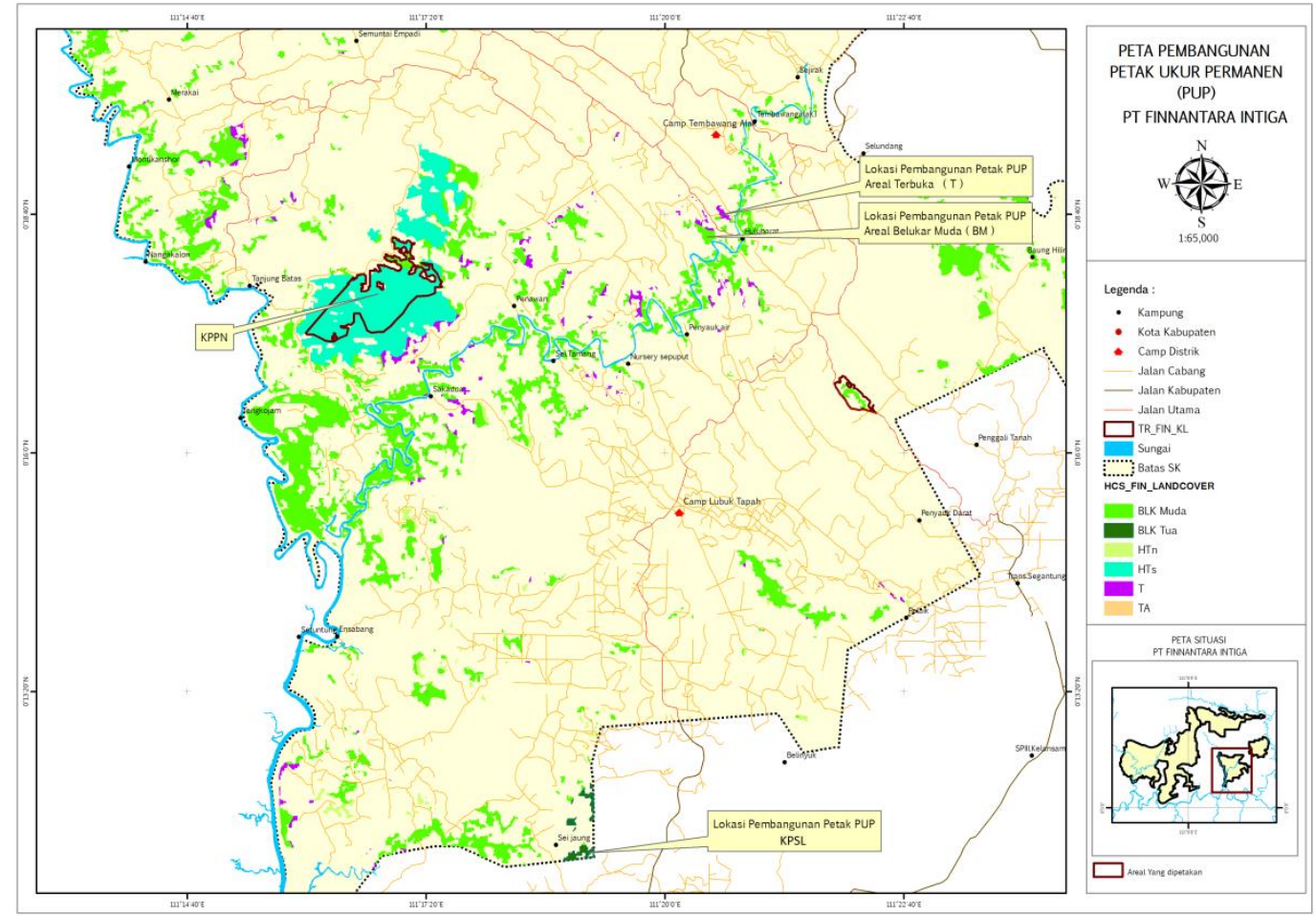

Gambar 1. Peta Lokasi Plot Pengukuran (Measurement Plot Location Map) 


\section{Bahan dan Alat Penelitian}

Bahan yang dijadikan sebagai objek penelitian ini adalah tumbuhan (vegetasi), mulai dari tingkat semai, pancang, tiang dan pohon. Bahan tersebut diambil pada vegetasi yang masih hidup di kawasan perlindungan. Alat yang digunakan dalam penelitian ini yaitu GPS (Global Positioning System), meteran, diameter tape, tali plastic, kamera, pisau/gunting stek, kantong plastik, alkohol, kertas Koran, alat-alat tulis dan thally sheet.

\section{Prosedur Penelitian}

Penelitian ini menggunakan penafsiran foto udara/citra tahun 2014 untuk lokasi hutan terdegradasi klasifikasi penutupan lahan semak belukar dan lahan terbuka, sementara untuk hutan referensi dilakukan pada areal kawasan perlindungan yaitu KPPN, KPSL dan sempadan sungai. Penelitian ini menggunakan metode survey dengan cara jalur berpetak (Nested Sampling). Pengamatan diawali dengan menentukan sampel. Sampel ditentukan dengan cara Purposive Sampling atau pengambilan sampel secara sengaja dengan memilih areal yang dianggap mewakili keadaan objek secara keseluruhan.
Pengamatan dilakukan dengan metode kombinasi antara metode jalur dengan garis berpetak. Jalur dibuat 5 jalur untuk tiap-tiap lokasi. Jalur tersebut dibuat sepanjang $500 \mathrm{~m}$ dengan lebar jalur $20 \mathrm{~m}$. Jarak antar plot dalam satu jalur sejauh $100 \mathrm{~m}$ dan jarak antara jalur sejauh $200 \mathrm{~m}$. Pada setiap jalur dibuat petak-petak pengamatan dengan luas yang berbeda-beda berdasarkan tingkat pertumbuhan vegetasinya. Semua pohon dan tiang diukur diameter serta dicatat jumlah dan nama jenisnya. Tingkat semai dan pancang hanya dihitung jumlah dan nama jenisnya. Kriteria untuk tingkat pohon, pancang dan semai adalah sebagai berikut (Kartawinata, 2016):

1. Pohon, dengan kriteria diameter setinggi dada $(1,3 \mathrm{~m}) \geq 20 \mathrm{~cm}$, bila pohon berbanir diameter diukur 20 $\mathrm{cm}$ di atas banir, ukuran plot $20 \mathrm{~m} \mathrm{x}$ $20 \mathrm{~m}$.

2. Tiang, dengan kriteria diameter setinggi dada $(1,3 \mathrm{~m})$ antara $10-20$ $\mathrm{cm}$, ukuran plot $10 \mathrm{~m} \times 10 \mathrm{~m}$.

3. Pancang, yaitu permudaan yang tingginya $>1,5 \mathrm{~m}$ sampai pohon muda dengan diameter $<10 \mathrm{~cm}$, ukuran plot $5 \mathrm{~m}$ x $5 \mathrm{~m}$.

4. Semai, yaitu permudaan mulai dari kecambah sampai tinggi $\leq 1,5 \mathrm{~m}$, ukuran plot $2 \mathrm{~m} \times 2 \mathrm{~m}$

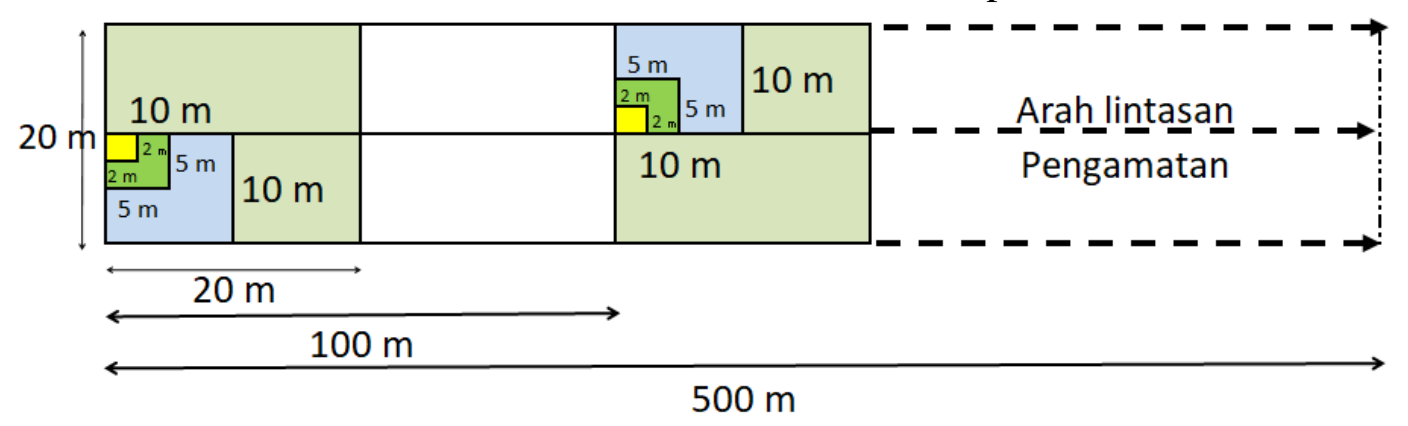

Gambar 2. Plot Pengukuran Penelitian (Research Measurement Plot) 


\section{Metode Analisis Data}

Hasil pengumpulan data di lokasi penelitian diolah untuk mendapatkan struktur dan komposisi yang ada di kawasan tersebut. Kemudian setiap jenis vegetasi dihitung Indeks Nilai Penting (INP), Indeks Keanekaragaman (H'), Indeks Kemerataan (E), Indeks Dominansi Jenis (C), Indeks Kesamaan Komunitas dan Pola Pemulihan hutan.

\section{Index Nilai Penting}

Komposisi pohon dan permudaannya, serta bentuk hidup tumbuhan lainnya dapat diketahui dengan menghitung index nilai penting (INP). INP juga dapat menggambarkan komposisi jenis dan tingkat penguasaan (dominansi) jenis dalam satu komunitas (Indriyanto, 2008) dengan cara menjumlahkan nilai kerapatan relatif (DR) dari suatu jenis tersebut. Perhitungan INP, digunakan beberapa rumus sebagai berikut:

1. Kerapatan Jenis $(\mathrm{K})=$ Jumlah individu suatu jenis / Luas plot pengamatan

2. Kerapatan Relatif $(\mathrm{KR})=$ (Kerapatan suatu jenis / Kerapatan seluruh jenis) x $100 \%$

3. Frekuensi Jenis $(\mathrm{F})=$ Jumlah plot ditemukannya suatu jenis / Jumlah total plot pengamatan

4. Frekuensi Relatif $(\mathrm{FR})=($ Frekuensi suatu jenis / Frekuensi sseluruh jenis) $\mathrm{x} 100 \%$

5. Dominansi Jenis $(\mathrm{D})=$ Luas bidang dasar suatu jenis / Luas plot pengamatan

6. Dominansi Relatif (DR) = (Dominansi suatu jenis / Dominansi seluruh jenis) $\mathrm{x} 100 \%$
Selanjutnya dihitung nilai Indeks Nilai Penting (INP) untuk mengetahui jenis dan tingkat tumbuhan yang dominan dengan rumus sebagai berikut:

1. Semai, Pancang : INP $=\mathrm{KR}+\mathrm{FR}$

2. Tiang, Pohon: $I N P=K R+F R+D R$

\section{Index Keanekaragaman Jenis}

Analisa Index Keanekaragaman Jenis ( $H^{\prime}$ ) dihitung menggunakan rumus keanekaragaman jenis Shannon-Weiner (Magurran 1988) sebagai berikut :

$$
\begin{aligned}
H^{\prime} & =\sum_{i=1}^{s} p_{i} \cdot \ln \left(p_{i}\right) \\
p_{i} & =\frac{n_{i}}{N}=\frac{n_{i}}{\sum_{i=1}^{s} n_{i}}
\end{aligned}
$$

$\mathrm{H}^{\prime}$ = index keanekaragaman Shannon

$\mathrm{N}=$ total jumlah individu semua jenis yang ditemukan

$\mathrm{n}_{\mathrm{i}}=$ jumlah individu jenis ke- $\mathrm{i}$

$\mathrm{s} \quad=$ total jumlah jenis ditemukan

Terdapat tiga kriteria dalam analisis indeks keanekaragaman jenis yaitu jika $\mathrm{H}^{\prime}<1$, maka termasuk dalam kategori rendah, nilai $1<\mathrm{H}^{\prime}<3$, maka termasuk ke dalam kategori sedang dan akan dimasukkan ke dalam kategori baik bila H'> 3 (Magurran 1988).

\section{Index Kemerataan Individu per Jenis (Eveness Index)}

Indeks Kemerataan Jenis (E) menunjukkan tingkat kemerataan individu per jenis. Jika nilai E semakin mendekati 1, maka nilai kemerataannya semakin tinggi. Nilai E (Pielou 1975 dalam Magurran 1988) dihitung menggunakan rumus matematis sebagai berikut : 


$$
\mathrm{E}=\frac{H^{\prime}}{\ln (S)}
$$

$\mathrm{E}=$ indeks kemerataan jenis

$\mathrm{H}^{\prime}=$ indeks keanekaragaman jenis

$\mathrm{S}$ = jumlah jenis yang ditemukan

Menurut Magurran (1988) besaran E < 0,3 menunjukkan kemerataan jenis yang rendah, $0,3<\mathrm{E}<0,6$ menunjukkan tingkat kemerataan jenis yang sedang dan $\mathrm{E}>0,6$ menunjukkan tingkat kemerataan jenis yang tinggi.

\section{Index Dominansi Jenis (C)}

Indeks dominansi Jenis bertujuan untuk mengetahui pemusatan atau penguasaan suatu jenis pada suatu areal yang menggunakan rumus matematis (Simpson 1949 dalam Misra 1980) sebagai berikut :

$$
\mathrm{C}=\sum_{i=1}^{n}\left(\frac{n_{i}}{N}\right)^{2}
$$

$\mathrm{C}=$ indeks dominansi jenis

$\mathrm{n}_{\mathrm{i}}=$ kerapatan ke-i

$\mathrm{N}=$ total kerapatan

Nilai indeks dominansi jenis berkisar 0 $\leq \mathrm{C} \leq 1$, apabila suatu tegakan hanya dikuasai oleh satu jenis saja maka nilai $\mathrm{C}$ akan mendekati 1; dengan kata lain telah terjadi pengelompokan/pemusatan suatu jenis tumbuhan. Sebaliknya jika nilai $\mathrm{C}$ mendekati nilai 0 , maka tidak terjadi pemusatan jenis dimana terdapat beberapa jenis mendominasi secara bersama-sama.

\section{Index Kesamaan Komunitas}

Indeks kesamaan komunitas atau index of similarity diperlukan untuk mengetahui tingkat kesamaan antar komunitas di habitat yang diamati. Indeks ini menurut Soerianegara dan Indrawan (2005) dapat dicari dengan menggunakan rumus:

\section{IS $=(2 \mathrm{~W} /(a+b)) \times 100 \%$}

IS = Indeks kesamaan jenis

$\mathrm{W}=$ Jumlah spesies yang sama terdapat dalam kedua komunitas;

a = Jumlah spesies dalam komunitas a

$\mathrm{b}=$ Jumlah spesies dalam komunitas $\mathrm{b}$

Tingkat pengelompokan tipe antara dua komunitas dapat dikategorikan menjadi tiga tingkat yang berbeda (Magurran, 1988) yaitu sama sekali berbeda apabila nilai IS $<50 \%$ ), mirip apabila nilai $50 \% \leq$ IS $<75 \%$ dan dianggap sama apabila nilai IS $\geq 75 \%$.

\section{Pola Pemulihan Lahan}

Kondisi lokasi terdegradasi klasifikasi penutupan lahan semak belukar dan lahan terbuka menggunakan penafsiran foto udara/citra tahun 2014. Setelah selang waktu 6 tahun, perlu ditentukan pola pemulihannya sebelum dilakukan restorasi. Tidak banyak referensi yang mengatur pola pemulihan hutan, kebanyakan sudah ditentukan polanya dengan pengkayaan, terutama di areal hutan produksi. Penentuan pola pemulihan hutan ini merujuk pada Pedoman Tata Cara Restorasi di Kawasan Konservasi (JICA, 2014). Gambar 1. Menampilkan Skema Pemilihan Pola Pemulihan Hutan menurut JICA 2014. 


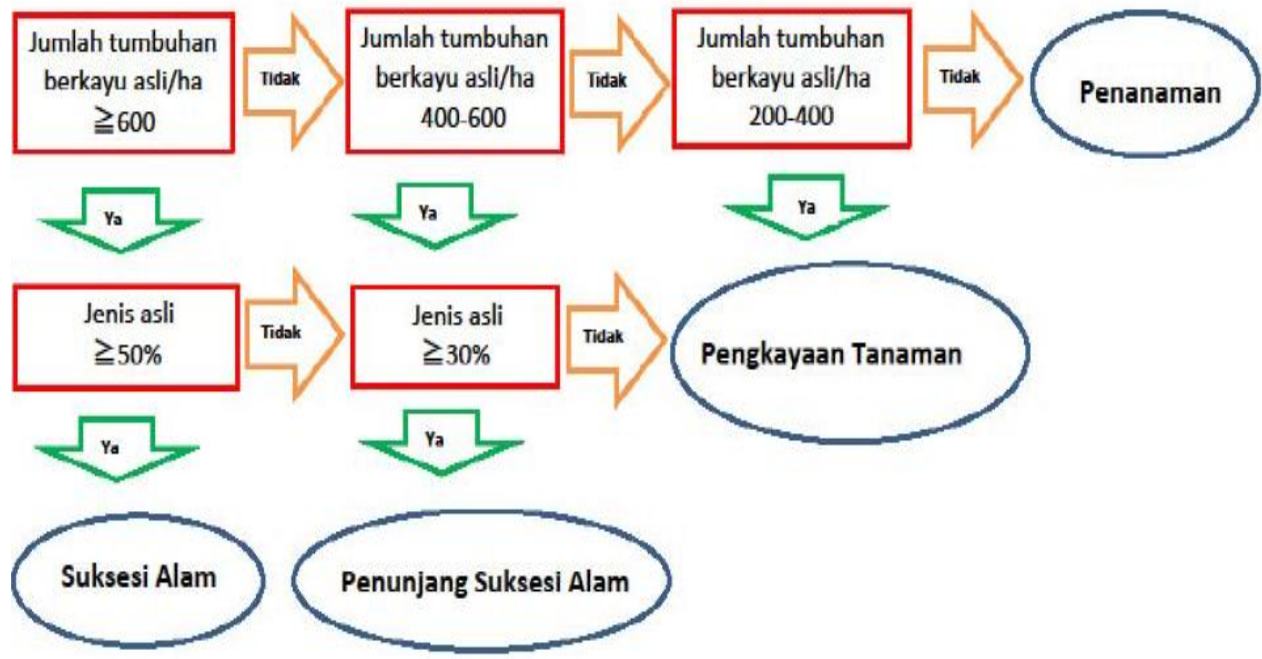

Gambar 3. Skema Pemilihan Pola Pemulihan Hutan menurut JICA 2014 (Scheme for Selecting Patterns of Forest Recovery According to JICA 2014 )

\section{Penentuan Jenis Vegetasi Terpilih}

Berdasarkan pengalaman kegiatan rehabilitasi dan reboisasi yang telah dilaksanakan sering kali terjadi kegagalan akibat ketidaksesuaian pemilihan jenis vegetasi yang akan ditanam. Jenis vegetasi untuk restorasi sebaiknya adalah jenis lokal (indegenous species) dengan pertimbangan utama bahwa jenis lokal memenuhi aspek ekologis yang sesuai dengan kondisi lokasi. Penentuan jenis vegetasi pada prinsipnya diharapkan sama dengan jenis pohon yang terdapat pada ekosistem hutan alam yang ada di dekat areal restorasi. Jumlah jenis pohon yang ditanam disarankan paling sedikit 30\% dari ekosistem hutan alam yang ada di dekat areal restorasi (JICA, 2014).

\section{HASIL DAN PEMBAHASAN}

\section{A. Hasil}

\section{Komposisi Vegetasi}

Hasil yang didapat secara umum dapat diringkas seperti tabel 1. 
JURNAL TENGKAWANG (2021)

Vol. 11 (2): 71 - 86

Tabel 1. Kerapatan dan jumlah jenis vegetasi (Density and number of vegetation types)

\begin{tabular}{|c|c|c|c|c|c|}
\hline Lokasi & No & Tingkat & Kerapatan (btg/ha) & Jumlah Jenis & $\begin{array}{l}\text { Jenis yang ada di } \\
\text { semua tingkat }\end{array}$ \\
\hline \multirow[t]{4}{*}{ KPPN } & 1 & Semai & 43.400 & 18 & \multirow{4}{*}{11} \\
\hline & 2 & Pancang & 19.680 & 27 & \\
\hline & 3 & Tiang & 2.312 & 27 & \\
\hline & 4 & Pohon & 997 & 25 & \\
\hline \multirow[t]{4}{*}{ KPSL } & 1 & Semai & 36.300 & 16 & \multirow{4}{*}{9} \\
\hline & 2 & Pancang & 11.488 & 24 & \\
\hline & 3 & Tiang & 1.832 & 25 & \\
\hline & 4 & Pohon & 655 & 26 & \\
\hline Sempadan & 1 & Semai & 46.125 & 27 & \multirow{4}{*}{8} \\
\hline \multirow[t]{3}{*}{ Sungai } & 2 & Pancang & 7.840 & 33 & \\
\hline & 3 & Tiang & 1.440 & 28 & \\
\hline & 4 & Pohon & 885 & 42 & \\
\hline Semak & 1 & Semai & 21.400 & 21 & \multirow{4}{*}{7} \\
\hline \multirow[t]{3}{*}{ Belukar } & 2 & Pancang & 3.920 & 54 & \\
\hline & 3 & Tiang & 456 & 41 & \\
\hline & 4 & Pohon & 245 & 53 & \\
\hline Lahan & 1 & Semai & 7.000 & 13 & \multirow{4}{*}{4} \\
\hline \multirow[t]{3}{*}{ terbuka } & 2 & Pancang & 1.952 & 22 & \\
\hline & 3 & Tiang & 88 & 13 & \\
\hline & 4 & Pohon & 22 & 11 & \\
\hline
\end{tabular}

Kondisi hutan di lokasi KPPN, KPSL sedangkan di lokasi lahan terbuka dan Sempadan Sungai masih kategori baik. Tegakan tingkat pohon masih mengalami degradasi karena ada bekas kebakaran. Tegakan tingkat pohon terlihat rapat. Kondisi hutan di lokasi semak belukar sedikit terganggu untuk kedua lokasi tersebut terlihat jarang.

dikarenakan ada bekas tebangan kayu, 
Tabel 2. Indeks Nilai Penting (INP) tertinggi tingkat semai, pancang, tiang dan pohon (Highest Importance Value Index (IVI) on seedling, sapling, pole and tree growth levels site)

\begin{tabular}{lcllll}
\hline \multicolumn{1}{c}{ Lokasi } & No & Tingkat & $\begin{array}{c}\text { INP } \\
\text { tertinggi }\end{array}$ & $\begin{array}{c}\text { Nama } \\
\text { Lokal }\end{array}$ & \multicolumn{1}{c}{ Nama Ilmiah } \\
\hline KPPN & 1 & Semai & 45.10 & Nyatoh & Palaquium rostratum (Miq.) Burck \\
& 2 & Pancang & 24.80 & Merebung & Maccaranga gigantea Muell.Arg. \\
& 3 & Tiang & 50.71 & Prepat & Combretocarpus rotundatus (Miq.) Danser \\
& 4 & Pohon & 84.08 & Prepat & Combretocarpus rotundatus (Miq.) Danser \\
KPSL & 1 & Semai & 54.17 & Penduk & Porterandia sp. \\
& 2 & Pancang & 51.65 & Penduk & Porterandia sp. \\
& 3 & Tiang & 43.16 & Penduk & Porterandia sp. \\
Sempadan & 4 & Pohon & 56.33 & Prepat & Combretocarpus rotundatus (Miq.) Danser \\
Sungai & 1 & Semai & 22.74 & Medang & Litsea sp. \\
& 2 & Pancang & 22.71 & Medang & Litsea sp. \\
& 3 & Tiang & 27.26 & Kelansau & Dryobalaops abnormis V.Sl. \\
Semak & 4 & Pohon & 35.44 & Pelaik Pipit & Alstonia angustifolia Wall. ex A. DC. \\
Belukar & 1 & Semai & 75.25 & Ubah putih & Eugenia spp. \\
& 2 & Pancang & 30.37 & Ubah putih & Eugenia spp. \\
& 3 & Tiang & 41.81 & Medang & Litsea sp. \\
Lahan & 4 & Pohon & 42.20 & Ubah putih & Eugenia spp. \\
terbuka & 1 & Semai & 63.33 & Jengger & Planchonia grandis Ridl \\
& 2 & Pancang & 63.55 & Jengger & Planchonia grandis Ridl \\
& 3 & Tiang & 63.61 & Temau & Cratoxylon sp \\
& 4 & Pohon & 64.02 & Rengas & Gluta renghas L. \\
\hline
\end{tabular}

Indeks Keanekaragaman Jenis (H'), Indeks Kemerataan Jenis (E) dan Indeks Dominansi Jenis (C)

Hasil perhitungan Indeks Keanekaragaman Jenis, Indeks Kemerataan Jenis dan Indeks Dominansi Jenis disajikan dalam tabel 3. Berdasarkan perhitungan yang terdapat pada tabel 3, di lokasi KPSL, KPPN, sempadan sungai, semak belukar dan lahan terbuka pada tingkat pertumbuhan semai, pancang, tiang dan pohon menunjukkan bahwa indeks keanekaragaman jenis di seluruh lokasi rata-rata bernilai sedang. Sempadan sungai tingkat tiang dan pohon serta pada semak belukar tingkat pancang, tiang dan pohon bernilai baik. Indeks kemerataan jenis untuk seluruh lokasi pada seluruh tingkat pertumbuhan bernilai tinggi. Data yang ada menunjukkan bahwa pada seluruh tingkatan pertumbuhan tidak terdapat pemusatan individu spesies tertentu pada suatu wilayah yang artinya keseluruhan individu suatu spesies tersebar merata pada semua wilayah. 
Tabel 3. Hasil perhitungan Indeks Keanekaragaman Jenis (H'), Indeks Kemerataan Jenis (E) dan Indeks Dominansi Jenis (C) untuk tingkat pertumbuhan semai, pancang, tiang dan pohon (Result of Diversity index (H'), Evenness Index (E) and Dominance Index for seedlings, saplings, poles and trees)

\begin{tabular}{|c|c|c|c|c|c|c|c|c|}
\hline Lokasi & $\begin{array}{c}\text { Tingkat } \\
\text { Pertumbuhan }\end{array}$ & $\mathrm{H}^{\prime}$ & Status & $\mathrm{E}$ & Status & C & Status & Keterangan \\
\hline \multirow[t]{4}{*}{ KPSL } & Semai & 2.14 & Sedang & 0.77 & Tinggi & 0.16 & Tidak ada & \\
\hline & Pancang & 2.45 & Sedang & 0.77 & Tinggi & 0.14 & Tidak ada & \\
\hline & Tiang & 2.60 & Sedang & 0.78 & Tinggi & 0.09 & Tidak ada & \\
\hline & Pohon & 2.38 & Sedang & 0.71 & Tinggi & 0.13 & Tidak ada & $H^{\prime}<1=$ rendah \\
\hline \multirow[t]{4}{*}{ KPPN } & Semai & 2.27 & Sedang & 0.79 & Tinggi & 0.15 & Tidak ada & $1<\mathrm{H}^{\prime}<3=$ sedang \\
\hline & Pancang & 2.82 & Sedang & 0.84 & Tinggi & 0.08 & Tidak ada & $\mathrm{H}^{\prime}>3=$ baik \\
\hline & Tiang & 2.52 & Sedang & 0.76 & Tinggi & 0.11 & Tidak ada & \\
\hline & Pohon & 2.48 & Sedang & 0.77 & Tinggi & 0.14 & Tidak ada & $\mathrm{E}<0,3=$ rendah \\
\hline \multirow[t]{4}{*}{ S. Sungai } & Semai & 2.85 & Sedang & 0.87 & Tinggi & 0.07 & Tidak ada & $0,3<E<0,6=$ sedang \\
\hline & Pancang & 2.90 & Sedang & 0.83 & Tinggi & 0.07 & Tidak ada & $E>0,6=$ tinggi \\
\hline & Tiang & 3.07 & Baik & 0.91 & Tinggi & 0.06 & Tidak ada & \\
\hline & Pohon & 3.24 & Baik & 0.85 & Tinggi & 0.06 & Tidak ada & $C \sim 1=$ ada pemusatan \\
\hline \multirow[t]{4}{*}{ BM } & Semai & 2.28 & Sedang & 0.73 & Tinggi & 0.16 & Tidak ada & $\begin{array}{l}\mathrm{C} \sim 0=\text { tidak ada } \\
\text { pemusatan }\end{array}$ \\
\hline & Pancang & 3.00 & Baik & 0.73 & Tinggi & 0.09 & Tidak ada & \\
\hline & Tiang & 3.24 & Baik & 0.86 & Tinggi & 0.06 & Tidak ada & \\
\hline & Pohon & 3.41 & Baik & 0.81 & Tinggi & 0.05 & Tidak ada & \\
\hline \multirow[t]{4}{*}{ LT } & Semai & 2.09 & Sedang & 0.79 & Tinggi & 0.17 & Tidak ada & \\
\hline & Pancang & 2.01 & Sedang & 0.64 & Tinggi & 0.24 & Tidak ada & \\
\hline & Tiang & 2.39 & Sedang & 0.90 & Tinggi & 0.11 & Tidak ada & \\
\hline & Pohon & 2.17 & Sedang & 0.91 & Tinggi & 0.14 & Tidak ada & \\
\hline
\end{tabular}

Indeks Kesamaan Komunitas

Hasil perhitungan Indeks Kesamaan Komunitas disajikan dalam tabel 4.

Tabel 4. Hasil perhitungan Indeks Kesamaan Komunitas (Community Similarity Index calculation results)

\begin{tabular}{lrrrrr}
\hline Lokasi & \multicolumn{1}{l}{ KPSL } & \multicolumn{1}{l}{ KPPN } & \multicolumn{1}{l}{ SS } & \multicolumn{2}{l}{ SB } \\
\hline KPSL & & $58.67 \%$ & $40.86 \%$ & $52.03 \%$ & $40.00 \%$ \\
KPPN & $58.67 \%$ & & $36.96 \%$ & $40.98 \%$ & $52.17 \%$ \\
SS & $40.86 \%$ & $36.96 \%$ & & $48.57 \%$ & $32.18 \%$ \\
SB & $52.03 \%$ & $40.98 \%$ & $48.57 \%$ & & $39.32 \%$ \\
LT & $40.00 \%$ & $52.17 \%$ & $32.18 \%$ & $39.32 \%$ & \\
\hline
\end{tabular}

Perbandingan komposisi jenis lokasi KPSL, KPPN, Sempadan Sungai, Semak Belukar dan Lahan Terbuka untuk melihat tingkat kesamaan komunitas dapat dilihat pada tabel 4. KPSL memiliki kemiripan komunitas 
dengan KPPN dan Semak Belukar dengan nilai indeks berturut-turut $58,67 \%$ dan $52,03 \%$. KPSL tidak memiliki kemiripan komunitas dengan Sempadan Sungai dan Lahan Terbuka dengan nilai indeks berturut-turut sebesar 40,86\% dan 40,00\%. KPPN memiliki kemiripan komunitas dengan KPSL dan Lahan Terbuka dengan nilai indeks berturut-turut $58,67 \%$ dan $52,17 \%$. KPPN tidak memiliki kemiripan komunitas dengan Sempadan Sungai dan Semak Belukar dengan indeks berturut-turut $36,96 \%$ dan sebesar 40,96\%. Sempadan Sungai tidak memiliki kemiripan komunitas dengan lokasi manapun, karena keempat lokasi lainnya berada pada ekosistem daratan

\section{Struktur Hutan}

Struktur tegakan hutan adalah sebaran individu tumbuhan yang membentuk tegakan dalam suatu ruang. Struktur ini dapat dilihat berdasarkan kerapatan individu tingkat semai, pancang, tiang dan pohon. Struktur tegakan hutan berdasarkan ketersediaan tingkat permudaan ditunjukkan pada gambar 4. Gambar 4 menunjukkan bahwa pohon berukuran kecil cenderung lebih rapat dibandingkan dengan pohon berukuran besar. Struktur tegakan horizontal cenderung mendekati bentuk sebaran huruf $\mathrm{J}$ terbalik yang terbentuk di semua lokasi. Kurva tersebut menunjukkan bahwa kondisi hutan berada dalam kondisi yang seimbang dimana tingkat permudaan tersedia dalam jumlah yang cukup (tingkat semai > tingkat pancang $>$ tingkat tiang > tingkat pohon) dan terjaminnya kelangsungan regenerasi dari permudaan tersebut (Dendang et al., 2015).

Secara umum bentuk grafik struktur horizontal tegakan hutan pada ekosistem hutan yang mengalami kerusakan berada di bawah grafik struktur horizontal tegakan hutan alam yang menjadi referensi. Hal ini menunjukkan bahwa tingkat kerapatan vegetasi pada lokasi semak belukar dan lahan terbuka mengalami penurunan sehingga diperlukan tindakan pemulihan hutan untuk meningkatkan kerapatan mendekati ekosistem hutan alam yang belum mengalami kerusakan. 


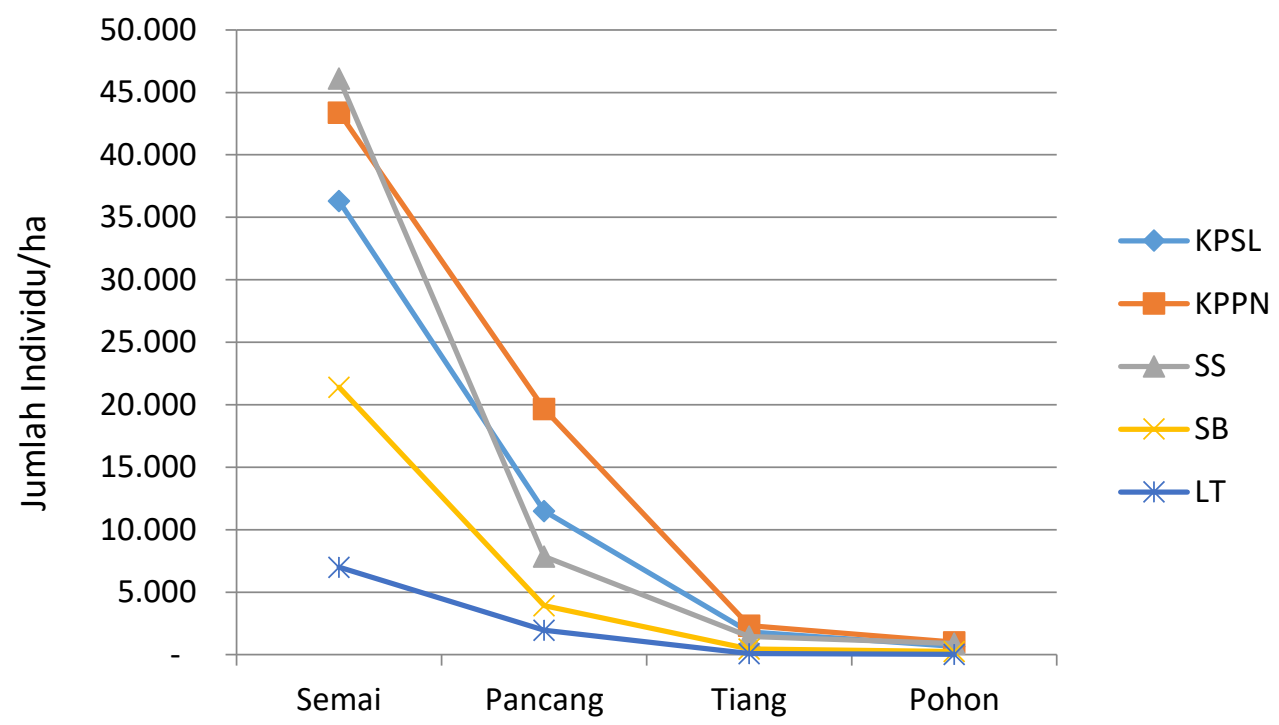

Gambar 4. Struktur tegakan berdasarkan ketersediaan tingkatan permudaan di lokasi KPSL, KPPN, Sempadan Sungai, Semak Beluka dan Lahan Terbuka (Stand structure based on the availability of youth level at the KPSL, KPPN, River Border, shrubs and open area location)

\section{Pola Pemulihan Hutan}

Penentuan arah pola pemulihan hutan dilakukan dengan analisis data hasil tegakan merujuk pada Pedoman Tata Cara Restorasi di Kawasan Konservasi (JICA, 2014) . Ada empat besar pola pemulihan yang akan dilaksanakan yaitu suksesi alami, penunjang suksesi alami, pengkayaan dan penanaman total. Hasil perhitungan pola pemulihan lahan merujuk pada Pedoman Tata Cara Restorasi di Kawasan Konservasi (JICA, 2014) disajikan pada tabel 5.

Tabel 5. Penentuan pola pemulihan hutan berdasarkan JICA 2014 (Determination of forest recovery patterns based on JICA 2014)

\begin{tabular}{lcccccc}
$\begin{array}{c}\text { Syarat } \\
\text { Pemulihan }\end{array}$ & $\begin{array}{c}\text { Suksesi } \\
\text { Alami }\end{array}$ & $\begin{array}{c}\text { Penunjang } \\
\text { Suksesi } \\
\text { Alami }\end{array}$ & Pengkayaan & Penanaman & SB (btg/ha) & LT (btg/ha) \\
\hline $\begin{array}{l}\text { Jumlah } \\
\text { Pohon }\end{array}$ & $\begin{array}{c}\geq 600 \\
\mathrm{btg} / \mathrm{ha}\end{array}$ & $\begin{array}{c}400-600 \\
\mathrm{btg} / \mathrm{ha}\end{array}$ & $\begin{array}{c}200-400 \\
\mathrm{btg} / \mathrm{ha}\end{array}$ & $\begin{array}{c}\leq 200 \\
\mathrm{btg} / \mathrm{ha}\end{array}$ & 1.954 & 1.621 \\
$\begin{array}{l}\text { Kemiripan } \\
\text { dengan } \\
\text { referensi }\end{array}$ & $\geq 50 \%$ & $\geq 30 \%$ & - & - & $52,63 \%$ & $52,78 \%$ \\
\hline $\begin{array}{c}\text { Pola } \\
\text { Pemulihan }\end{array}$ & & & & Suksesi & Suksesi \\
\end{tabular}


Tabel 6. Perhitungan jumlah Kerapatan tumbuhan berkayu dengan tinggi $>30 \mathrm{~cm}$ (btg/ha) di semak belukar (Calculation of the total density of woody plants with a height $>30 \mathrm{~cm}$ (ind/ha) in the shrubs)

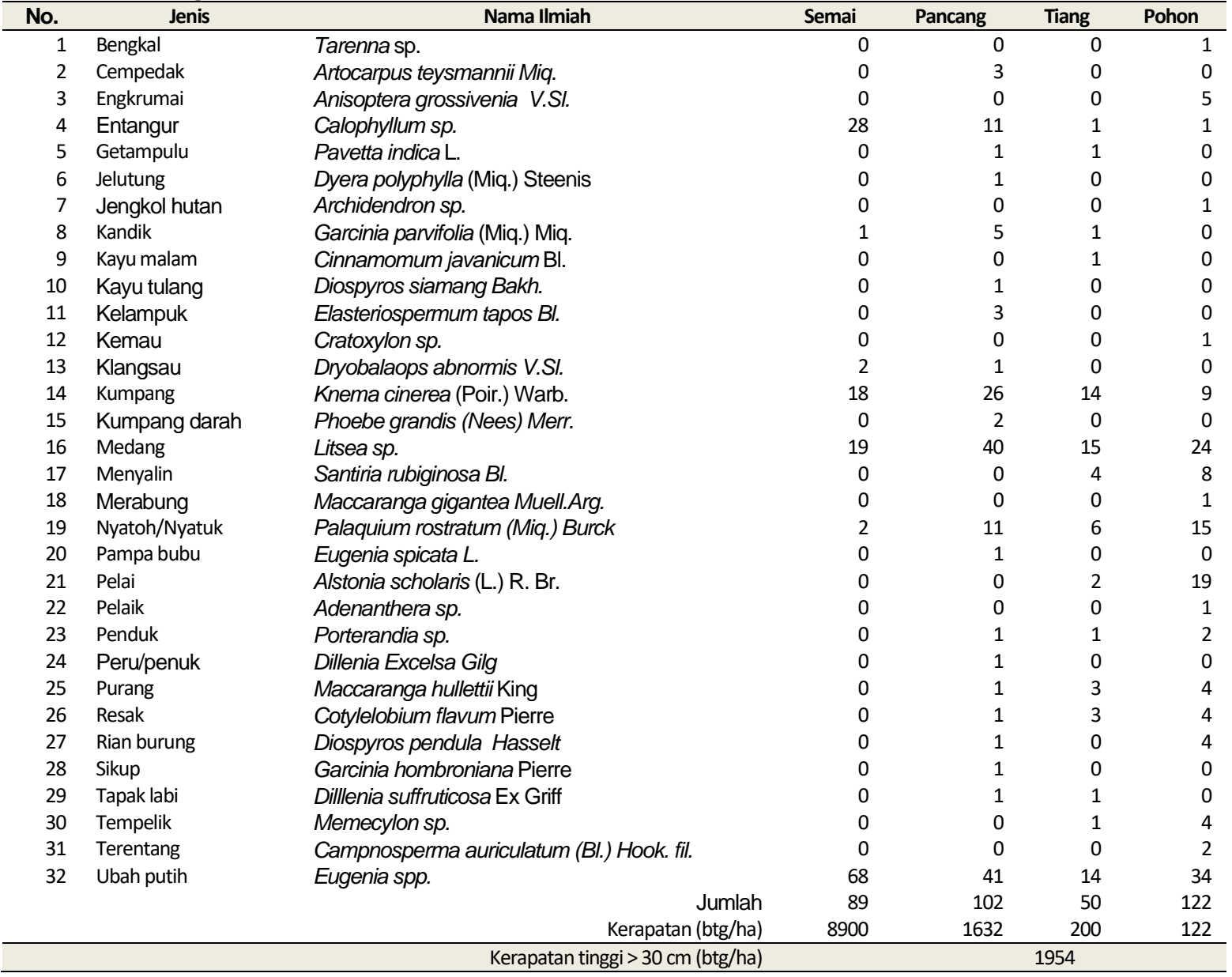

Tabel 7. Perhitungan jumlah Kerapatan tumbuhan berkayu dengan tinggi $>30 \mathrm{~cm}$ (btg/ha) di lahan terbuka (Calculation of the total density of woody plants with a height $>30 \mathrm{~cm}$ (ind/ha) in open land areas)

\begin{tabular}{|c|c|c|c|c|c|c|}
\hline No. & Jenis & Nama Ilmiah & Semai & Pancang & Tiang & Pohon \\
\hline 1 & Engkrumai & Anisoptera grossivenia V.SI. & 2 & 0 & 0 & 1 \\
\hline 2 & Mentangur & Calophyllum pulcherrinum Wall. & 0 & 0 & 1 & 0 \\
\hline 3 & Kayu malam & Cinnamomum javanicum BI. & 2 & 1 & 1 & 1 \\
\hline 4 & Temau & Cratoxylon sp. & 2 & 38 & 5 & 3 \\
\hline 5 & Rian burung & Diospyros pendula Hasselt & 2 & 4 & 0 & 0 \\
\hline 6 & Kelansau & Dryobalaops abnormis V.S.I & 17 & 0 & 0 & 0 \\
\hline 7 & Ubah putih & Eugenia spp. & 6 & 2 & 3 & 4 \\
\hline 8 & Rengas & Gluta renghas $L$. & 0 & 2 & 2 & 5 \\
\hline 9 & Engkajang & Kingiodendron sp. & 6 & 0 & 0 & 0 \\
\hline 10 & Kumpang & Knema cinerea (Poir.) Warb. & 0 & 1 & 0 & 0 \\
\hline 11 & Empilik & Lithocarpus elegans (Blume) Hatus. ex Soepadmo & 0 & 0 & 0 & 1 \\
\hline 12 & Merebung & Maccaranga gigantea Muell.Arg. & 0 & 0 & 0 & 1 \\
\hline 13 & Temulik & Memecylon sp. & 0 & 1 & 0 & 0 \\
\hline 14 & Merkulat & Mezzetia purtifolia Becc. & 0 & 1 & 0 & 0 \\
\hline 15 & Jongger & Planchonia grandis Ridl & 21 & 45 & 0 & 0 \\
\hline 16 & Penduk & Porterandia sp. & 5 & 2 & 0 & 0 \\
\hline 17 & Tunang & Shorea lamellata Foxw. & 0 & 0 & 0 & 1 \\
\hline \multirow[t]{4}{*}{18} & Ubah merah & Syzygium sp. & 0 & 0 & 1 & 0 \\
\hline & & Jumlah & 63 & 97 & 13 & 17 \\
\hline & & Kerapatan (btg/ha) & 6300 & 1552 & 52 & 17 \\
\hline & & Kerapatan tinggi > $30 \mathrm{~cm}$ (btg/ha) & & & 1621 & \\
\hline
\end{tabular}


Menurut hasil perhitungan, pola pemulihan yang disarankan adalah suksesi alami. Kegiatan yang dilakukan pada pola suksesi alami adalah (1) melakukan patroli dan penjagaan agar terhindar dari gangguan yang menghambat pertumbuhan vegetasi. Gangguan tersebut dapat berupa penggembalaan liar,kebakaran hutan, pemotongan tumbuhan karena mencari rumput, hama dan satwa (2) membuat sekat bakar (3) pembangunan pagar hidup (4) monitoring pertumbuhan anakan alam (JICA, 2014).

\section{Pemilihan Jenis Vegetasi Terpilih}

Berdasarkan pengalaman kegiatan rehabilitasi dan reboisasi yang telah dilaksanakan sering kali terjadi kegagalan akibat ketidaksesuaian pemilihan jenis vegetasi yang akan ditanam. Jenis vegetasi untuk restorasi sebaiknya adalah jenis lokal (indegenous species) dengan pertimbangan utama bahwa jenis lokal memenuhi aspek ekologis yang sesuai dengan kondisi lokasi. Penentuan jenis vegetasi pada prinsipnya diharapkan sama dengan jenis pohon yang terdapat pada ekosistem hutan alam yang ada di dekat areal restorasi. Jumlah jenis pohon yang ditanam disarankan paling sedikit 30\% dari ekosistem hutan alam yang ada di dekat areal restorasi (JICA, 2014).

Berdasarkan hasil perhitungan indeks kesamaan jenis, untuk lokasi semak belukar kecenderungan memiliki kemiripan dengan lokasi KPSL sebagai referensi dengan indeks sebesar $52,03 \%$. Ini berarti untuk kegiatan pengkayaan dan penanaman di lokasi semak belukar dapat menggunakan vegetasi dominan yang ada di lokasi KPSL pada tingkat pohon. Tabel 8 menyajikan nama-nama vegetasi dengan jumlah minimal $30 \%$ dari hutan yang dijadikan referensi.

Tabel 8. Jenis prioritas kegiatan pengkayaan dan penanaman di lokasi semak belukar (Priority types of enrichment and planting activities in shrubs areas)

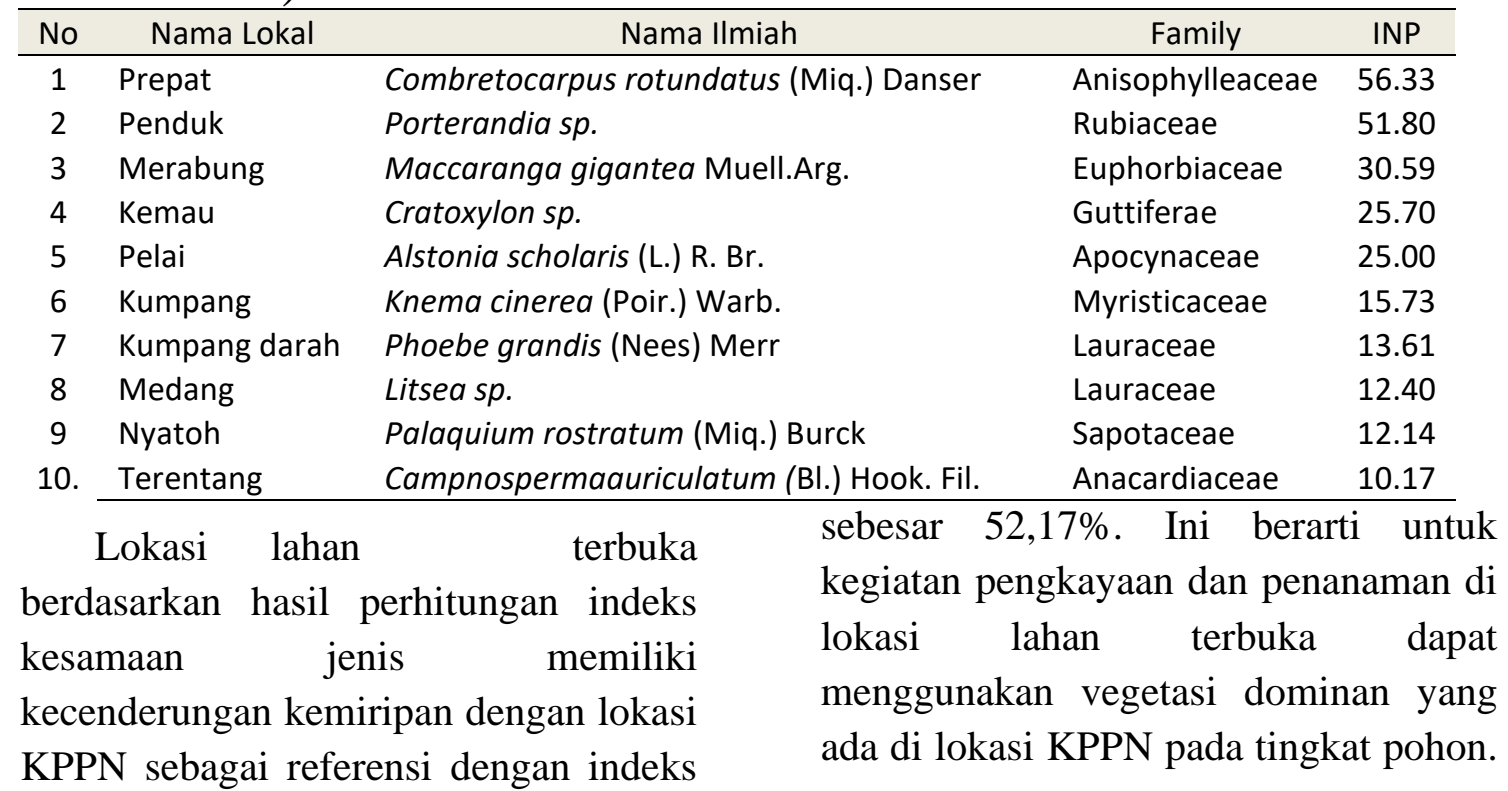


Tabel 9 menyajikan nama-nama dari hutan yang dijadikan referensi. vegetasi dengan jumlah minimal $30 \%$

Tabel 9. Jenis prioritas kegiatan penanaman di lokasi lahan terbuka (Priority types of planting activities in open land area)

\begin{tabular}{|c|c|c|c|c|}
\hline No. & Nama Lokal & Nama Ilmiah & Family & INP \\
\hline 1 & Prepat & $\begin{array}{l}\text { Combretocarpus rotundatus (Miq.) } \\
\text { Danser }\end{array}$ & Anisophylleaceae & 84.08 \\
\hline 2 & Nyatuk & Palaquium rostratum (Miq.) Burck & Sapotaceae & 21.64 \\
\hline 3 & Merebung & Maccaranga gigantea Muell.Arg. & Euphorbiaceae & 21.62 \\
\hline 4 & Empetir & Kingiodendron sp. & Caesalpiniaceae & 20.91 \\
\hline 5 & Entagor & Calophyllum sp. & Guttiferae & 18.99 \\
\hline 6 & Kelansau & Dryobalaops abnormis V.S.l & Dipterocarpaceae & 15.52 \\
\hline 7 & Medang & Litsea $s p$. & Lauraceae & 13.46 \\
\hline 8 & Engkajang & Kingiodendron sp. & Caesalpiniaceae & 11.29 \\
\hline 9 & Jelutung & Dyera polyphylla (Miq.) Steenis & Apocynaceae & 11.14 \\
\hline 10 & Rengas & Gluta renghas $L$. & Anacardiaceae & 10.38 \\
\hline
\end{tabular}

\section{Kesimpulan}

Berdasarkan hasil analisis dan penelitian dapat digambarkan komposisi jenis, struktur vegetasi, pola pemulihan hutan dan pemilihan jenis terpilih sebagai berikut:

1. Jenis tumbuhan berkayu yang mendominasi lokasi KPSL adalah penduk (Porterandia $s p$ ) dan perepat (Combretocarpus rotundatus (Miq.) Danser). Jenis tumbuhan berkayu yang mendominasi lokasi KPPN adalah nyatoh (Palaquium rostratum (Miq.) Burck), Merabung (Maccaranga gigantea Muell.Arg.) dan perepat (Combretocarpus rotundatus (Miq.) Danser). Jenis tumbuhan berkayu yang mendominasi lokasi Sempadan Sungai adalah Pelaik Pipit (Alstonia angustifolia Wall. ex A. DC.), Medang (Litsea sp.) dan Kelansau (Dryobalaops abnormis V.Sl.). Jenis tumbuhan berkayu yang mendominasi lokasi Semak Belukar adalah ubah putih (Eugenia sp.) dan medang (Litsea sp.). Jenis tumbuhan berkayu yang mendominasi lokasi lahan terbuka adalah temau (Cratoxylon sp.) dan Rengas (Gluta renghas L). Secara umum bentuk grafik struktur horizontal tegakan hutan pada ekosistem hutan yang mengalami kerusakan berada di bawah grafik struktur horizontal tegakan hutan alam yang menjadi acuan. Hal ini menunjukkan bahwa tingkat kerapatan vegetasi pada lokasi semak belukar dan lahan terbuka mengalami penurunan sehingga diperlukan tindakan pemulihan hutan untuk meningkatkan kerapatan mendekati ekosistem hutan alam yang belum mengalami kerusakan.

2. Pola pemulihan lahan untuk areal semak belukar dan lahan terbuka merujuk pada Pedoman Tata Cara Restorasi di Kawasan Konservasi (JICA, 2014) adalah suksesi alami. Pola pemulihan hutan yang akan dilaksanakan harus mempertimbangkan kondisi fisik lapangan dan sosial budaya setempat. Kondisi Hutan yang tegakannya masih rapat bisa dengan suksesi alami saja, untuk kondisi hutan yang tegakannya jarang dapat dilakukan pengkayaan. Sementara Kondisi hutan yang cenderung terbuka dapat dilakukan penanaman. Antisipasi kondisi tertentu jika terjadi degradasi hutan, jenis vegetasi untuk kegiatan 
pengkayaan dan penanaman pada lokasi semak belukar mengacu pada lokasi KPSL sebagai referensi karena kecenderungan memiliki kemiripan dengan dengan indeks kesamaan komunitas sebesar 52,03\%. Jenis vegetasi untuk kegiatan pengkayaan dan penanaman pada lokasi lahan terbuka mengacu pada lokasi KPPN sebagai referensi karena kecenderungan memiliki kemiripan dengan indeks kesamaan komunitas sebesar $52,17 \%$.

\section{Saran}

1. Penanaman yang dilakukan pada lokasi lahan terbuka harus mengikuti kaidah yang ditentukan dalam Permen LHK No. P.105 / MENLHK / SETJEN/KUM.1/12/2018 tentang Tata Cara Pelaksanaan, Kegiatan Pendukung, Pemberian Insentif serta Pembinaan dan Pengendalian Kegiatan Rehabilitasi Hutan dan Lahan.

2. Lokasi yang mengalami degradasi hutan baru akibat perambahan, illegal logging maupun kebakaran hutan dapat menggunakan jenis vegetasi terpilih hasil kajian di atas untuk kegiatan restorasi.

\section{DAFTAR PUSTAKA}

BAPPENAS. 2016. Indonesian Biodiversity Strategy and Action Plan (IBSAP) 2015-2020. Bapdan Perencanaan Pembangunan Nasional. Jakarta

Dendang B, Handayani W. 2015. Struktur dan komposisi tegakan hutan di Taman Nasional Gunung Gede Pangrango, Jawa Barat. Proseding Seminar Nasional Masyarakat Biodiversity Indonesia. 4(1), pp.691-695.
[FI] PT Finnantara Intiga. 1996. Analisis mengenai dampak lingkungan pemanfaatan hasil hutan kayu pada hutan tanaman PT. Finnantara Intiga. Kalimantan Barat.

[FWI] Forest Watch Indonesia. 2018. Potret Keadaan Hutan Indonesia Periode 2000-2017. Forest Watch Indonesia. Bogor

JICA. 2014. Pedoman Tata Cara Restorasi di Kawasan KonservasiHutan Hujan Tropis Pegunungan dan Hutan Monsoon Tropis. JICA. Jakarta.

Indriyanto. 2006. Ekologi Hutan. Cetakan Pertama. Penerbit PT Bumi Aksara. Jakarta.

Kamada M. 2005. Hierarchically Structured Approuch for Restoring Natural Forest-Trial in Tokushima Prefecture, Shikoku, Japan. Landscape Ecology Engineering 1:61-70

Kartawinata K. 2016. Diversitas Ekosistem Alami Indonesia. Penerbit: Yayasan Pustaka Obor Indonesia

Magurran AE. 1988. Ecological Diversity and Its Measurement. Australia (AU): Croom Helm. Hlm:35-37

Misra KC. 1980. Manual of Plant Ecology (second edition). New Delhi (IN): Oxford and IBH Publishing Co.

Soerianegara I. dan Indrawan A. 2005. Ekologi Hutan Indonesia. Institut Pertanian Bogor, Bogor. 